\title{
"There is nothing more permanent than something temporary": historical retrospective of Siberian water infrastructure projects
}

\author{
Ilya Ageev ${ }^{1,2, a}$, Vasiliy Zinovyev ${ }^{3}$, and Anastasia Nikolaeva ${ }^{1}$ \\ ${ }^{1}$ National Research Tomsk Polytechnic University, Lenin Avenue 30, Tomsk 634050, Russia \\ 2 Tomsk State University of Control Systems and Radioelectronics, Lenin Aenue 40, Tomsk 634050, Russia \\ ${ }^{3}$ National Research Tomsk State University Lenin Avenue 36, Tomsk 634050, Russia
}

\begin{abstract}
The most famous historical project of transport infrastructure in Siberia is the Ob-Yenisei Canal. It was implemented at the end of the 19th century, however it was considered a failure and closed. A continuing interest in the Canal's construction and the circumstances of its origin demonstrates the special place of the Ob-Yenisei Canal in Russian historical memory. One of the causes of the construction's failure was the decision to reduce the size of the Ob-Yenisei Canal in the final draft. The article is devoted to identifying the reasons that influenced the decision to change the Canal's size, which determined the lack of capacity. The results showed that engineers were not satisfied with the results of research and looked for opportunities of additional reconnaissance. A number of economic indicators was impossible to detect without carrying out construction work. The authors concluded that the engineers allowed cutting the volume of construction works at the first stage, which was not due to the economy. It was connected with the ambition to collect information on the cost of building, living conditions and scale of labor organization in the taiga-unpopulated area without significant expenses. Developers wrongly relied on the subsequent modernization and expansion of the Canal.
\end{abstract}

\section{Introduction}

Ever since the economic development of Siberia, inland waterway transport has been one of the most important factors in the economic development of the region. In Soviet times, the river transport of Siberia received considerable attention [1]. The Soviet Union collapsed and shipping industry was stricken with a deep crisis because of the termination of government subsidies [2]. The search for an answer to the question: "Are the projects of Trans-Siberian water communication suggested by modern Russian researchers realistic?" can be facilitated by the study of historic reasons for a high financial risks of Siberian river transport.

The Ob-Yenisei Canal is one of the projects, which is known only due to the fact of its construction. However, in the context of Siberian transport development, the ObYenisei Canal showed an implementation complexity among major infrastructure projects aimed at the development of undeveloped and unexplored areas with harsh climate. Researchers want to find out both subjective and objective causes of the Ob-Yenisei Canal's failure.

The Canal was constructed at the end of the 19th century. After the official closing of the Ob-Yenisei Canal there were several suggestions to recover it,

\footnotetext{
a Corresponding author: agilalex@mail.ru
}

however each time there were no development because of objective impossibility to do so by climatic and economic reasons. One of the reasons, because of which the Canal did not gain the popularity, was a narrow construction of the Canal. Therefore, the Canal was unsuitable for most ships of $\mathrm{Ob}$ and Yenisei shipping. The purpose of the article is to define the reasons that influenced the decision to change the Canal's size, which determined the lack of the Canal capacity.

\section{Literature review}

The study of the problems of the sea and river transport development occupies an important place in the modern scientific field and is carried out using a variety of research strategies at the intersection of social, economic and human sciences [3-6]. In recent studies of the Russian water transport, the historical experience of the organization and operation of large-scale water facilities and transport infrastructure has not been practically involved [7-9]. However, it would allow identifying the historically conditioned risk factors of the modern water transport. Analysis of the degree of correlation of historical and modern problems of Siberian water transport forms a research gap, which is going to be filled by the current study. 
Scientific studies on the Ob-Yenisei Canal are not numerous. The research on the Canal began in the late 20th century [7]. Before that period only journalism was interested in that engineering experiment. An available scientific literature and journalistic sources include contradictory opinions about the reasons for the construction of Ob-Yenisei Canal beyond the size of ships. The first view, which is common for journalistic sources, explains this fact by saying that the Ob-Yenisei Canal was built deliberately narrow, under the influence of the lobby of merchants who worked in the field of transport. The second view, which appeared in historical discussions in the 1990s, links the decision to reduce the Canal's size with the fact that the State Council of the Russian Empire imposed the project with smaller dimensions to ensure practical benefits from that waterway directions by the example of small vessels [10].

\section{Research method and historical sources}

Along with the general scientific principles of the system and historicism, the authors rely on traditional tools of historical science - historical-genetic, comparative, typological, problem-chronological methods. This study employs the special methods that are included in the theory of post-industrial society. The improvement of railway in Siberia in the second half of the 19th century fit into the context of the transition of the region from pre-industrial to an industrial society therefore the attraction of the modernization theory does not lose its relevance. The Ob-Yenisei Canal demonstrates the duality of social and economic processes, for instance, attempts to meet the new industrial tasks using traditional, pre-industrial tools and techniques.

Sources on the history of the Ob-Yenisei Canal include:

1) Record management documents of the Ministry of Railways of the Russian Empire and its subordinate departments, stored in the Russian State Historical Archive (RSHA), St. Petersburg. In particular, the official documents of the financial, technical and administrative aspects of the construction and operation of the Canal.

2) The collection of printed notes - Special Fund of RSHA containing presentation and reporting materials about design and building of the Canal for State Council.

3) The complex of the printed materials of Siberian newspapers at the end of the 19th century: "Siberian Bulletin" (Tomsk, from 1885 to 1902) and "Eastern Review" (Irkutsk, from 1882 to 1906).

4) Technical Reports of engineers-auditors of the ObYenisei Canal issued in the form of the brochures and stored in the National Library of Russia (RSHA, St. Petersburg).

The documents describing the strategy for the development of the transport system of Russia as a whole and river transport in particular, posted on the website of the Ministry of Transport of the Russian Federation, became the sources of the current state of transport. Working with archival documents (reports of engineers working on the Ob-Yenisei Canal, auditor reports of government departments, journalistic articles), authors are basing on the method of discourse analysis. This analysis allows determining the "politics" of the text (author's conscious goal-setting), narrative and not narrative types of presentation in the text, inevitably conflicting figures of logic and rhetoric, the ways of structuring the content and means of author's expression.

\section{Results and discussion}

Proposals to build a canal from the $\mathrm{Ob}$ to the Yenisei was put forward a few times in the 19th century. This allowed saving a lot of money in comparison with railway construction. Yeniseisk merchant P.E. Funtusov found out the location for the Canal construction in 1872. P.E. Funtusov organized two expeditions to confirm the connectivity of the rivers Ket and Kas tributaries of the $\mathrm{Ob}$ and Yenisei in 1872 and 1873. The Ministry of communication lines was interested in Funtusov's discovery and commissioned an expedition to the area of the watershed of the $\mathrm{Ob}$ and the Yenisei to the Russian Geographical Society.

The Ministry of communication lines organized two expeditions to the drainage divide of the $\mathrm{Ob}$ and the Yenisei. In 1875, an expedition of engineers A.K. Sidensner and Moshkov took place. A conductor of the expedition was an engineer A.K. Sidensner. The engineers concluded that the best option was a connection path opened by Funtusov [11]. In addition to describing the rivers, difficulties have been listed. The studied rivers were not navigable even for small boats. They were very tortuous and rubble littered with trees, creating natural dams.

Engineers Sidensner and Moshkov stated that the construction cost would not exceed one million roubles. They concluded that the Canal construction for smaller vessels could not cost more than 500 thousand roubles. This figure was very undervalued in comparison with later calculations. Perhaps the engineers did not take into account transport costs, the costs of bringing the adjacent rivers in the state suitable for navigation.

According to materials from the Russian State Historical Archive (F. 180, Inv. 1, U. 155, Sh. 7, 8-13, $47,121-122)$, in 1877, another expedition was equipped to carry out a reconnaissance of another embodiment of the way - the rivers Ket, Sochur, Peschanka and Antsiferovka [12]. Engineer B. A. Aminov was appointed the head of the second expedition. Conclusions of the second expedition greatly enriched the information on the watershed. The description of rivers showed a lot of inconvenience to navigation, however these facts did not effect on the decision to build the Canal [12]. It should be mentioned that research results contained many inaccuracies. Both expeditions proved the possibility of the Canal construction.

When considering the possible sources of funding, the choice was made in favour of public money. All previous projects devoted to the connection of the $\mathrm{Ob}$ 
and Yenisei river basins were initiated by private persons - merchants. They wanted to finance their projects, but with the condition of the privileged use of the Canal. According to officials, the Canal construction using private funds means getting a monopoly controlled strategic direction shortly before the construction of railways in Siberia. State treasury was the only source of funding for the project of the Ob-Yenisei Canal, despite the financial deficit of the late 19th century.

In 1881, Bjork Aminov prepared a project of the $\mathrm{Ob}-$ Yenisei Canal in two variants - maximum (for ships of 80 tons displacement) and minimum (less costly design for ships of 8 tons) versions. The preliminary draft drawn up by an engineer B.A. Aminov, assumed the construction of the connecting path through the river Ket - the river Ozernaya - the river Lomovataya - the river Yazevaya - Bolshoye Vodorazdelnoye Lake - shipping canal seven miles long - the river Small Kas - the river Big Kas. Engineer B.A. Aminov was unable to develop a final draft, as the available information about the area was enough neither for the project itself, nor for the cost estimates. B.A. Aminov said that for the start of the construction the full research was necessary to obtain data on work volume, value and control method. Getting this information could only be experienced through the work.

March 24, 1881 a preliminary draft of the Ob-Yenisei Canal was approved by the Technical and Inspection Committee of the Ministry of communication lines. The cost of its implementation amounted to eight million roubles, and the total cost with the elimination of rapids on the Angara river was ten million roubles. This amount appeared to be ten times less than that required for the construction of the railway between Tomsk and Irkutsk [6]. However, at the stage of completion of the initial "maximum" variant of the draft, the possible dimensions of vessels were reduced. As a result, the Canal construction was carried out by a reduction in the dimensions of a "trial" version. The Ministry of communication lines approved the second, proof-ofconcept project and promised to finance additionally an upgrade in case of the canal efficiency. The Canal was built from 1884 to 1886 .

It is believed that the State Council insisted on a "trial" undersized version of the project due to the scarcity of the State Treasury and absence of compliancy with the plans of engineers [10]. However, primary sources indicate that the engineers did not exclude the possibility of a phased construction of the Ob-Yenisei Canal, starting with the arrangements for the movement of small boats. They mentioned this opportunity several times in the reports and papers devoted to the future Canal. A.K. Sidensner listed the possible work volume for the initial stage of the Canal construction in the report publication on the expedition of the 1875th year. The engineer pointed out that an available information is sufficient only to accommodate transportation by small vessels.

A.K. Sidensner outlined the work necessary for the organization of such a "miniature" connected river canal: "In this arrangement, the only need is to connect the upper reaches of the river Yazevaya and the river Small
Kas by means of the canal and straightening and clearing the riverbeds to the width of 7 yards and the depth of 4 feet" [11]. Officials were of the same opinion [12]. The Ministry of communication lines proposed to hurry to open the transportation by small boats. To ensure their transportation it was necessary only to dig a canal about 7 versts long through the isthmus from the lake Bolshoye up to the river Small Kas. The Ministry proposed to start the construction of this canal as a skilled work without waiting for the approval of projects. It was expected to gradually improve the stream channels of adjacent rivers later. The cost of the canal project was 383 thousand roubles. According to materials from the Russian State Historical Archive (F. 446, Inv. 28, U. 2, Sh. 39; F. 174, Inv. 1, U. 1524, Sh. 1; F. 176, Inv. 1, U. 4473, Sh. 37), the cost of development work and preparation of the project was estimated at 300 thousand roubles [12].

Thus, the decision to build the Ob-Yenisei Canal for small vessels was not a surprise. Engineers who led the study, did not preclude the implementation of the project of connecting canal in this way at the first stage. They stated the following arguments:

- the existence of the actual shipping from Tyumen to Kyahta and the simplicity of building a canal to connect the navigable river sections for the first time for small vessels;

- the construction of wooden Canal structures with the possibility of further restructuring with more reliable materials;

- the possibility of Canal expansion in case of traffic growth.

The final decision on the construction of the canal for small vessels was confirmed by the intervention of the Ministry of communication lines. Officials considered it possible to start the canal construction without "waiting for the results of additional research and full approval of projects" [12]. It was emphasized that the work was experimental. Because of the large risks, the government did not directly invest large amounts of money in poorlyresearched project that has no exact calculations of traffic.

Based on the suggestion that after the completion of preliminary work the reduced canal should be a complete construction, suitable for shipping, baron B.A. Aminov provided memorandum with proposals to reduce the cost of the waterway in the Technical and Inspection Committee in the spring of 1883 [12]. These changes were the basis for the final construction project, which was approved after the start of work in the spring of 1884 [12].

Therefore, to speed up work, the start of the Canal building was without an approved project and staff management, and with reduced dimensions - just for small boats - with a narrow riverbed (6 yards instead of 9) [13]. Cleaning of riverbeds was held instead of locks building. The ability to use the Ob-Yenisei Canal to facilitate the construction of the Trans-Siberian railway led to a hurried decision on the temporary nature of the Canal as well as the deficit the state treasury.

Despite the decision and a preliminary agreement on the allocation of money for the first phase of the Canal construction the petition with clearly costed and detailed 
project was required. Engineer B.A. Aminov was unable to provide a definitive estimate of the work cost, as he was not familiar with the conditions of works in the remote unpopulated area. He did not know the costs of labour in Siberia (especially newcomers), the cost of maintaining a large co-operative working with full clothes, food, accommodation and transportation from the residence to the work site. Anyone else could not imagine this information, as a way of labour organizing was used for the first time in the Tomsk government. An unprecedented task was set. It was necessary to create the infrastructure with the parallel start of the Canal construction within a short period of time.

B.A. Aminov offered to make trial works at first. He asked 680 thousand roubles for this stage of the construction [12]. In assessing the amount of work, for which he asked the said amount, B.A. Aminov found it insufficient to fully achieve the planned objectives. Despite the reduction in the project, B.A. Aminov was hoping to receive full funding in time, using funds originally allocated as the cost of "trial work".

The State Council used the lack of information about the watershed and other circumstances of the Canal drafting in their own interests. Officials wanted to open the transportation line as soon as possible and without any trial work - even for small boats, but soon. The State Council assessed the request of B.A. Aminov to allocate 680 thousand roubles for the trial work as unjustified. The State Council allocated 600 thousand roubles [12]. Thereby, the Ministry of communication lines and the State Council cut funding for the Ob-Yenisei Canal and believed that the problem of non-transshipment and easy navigation through the reduced canal can be solved with the construction of a large number of vessels with small dimensions. Due to the haste, the completion of the project for maximum canal dimensions was postponed indefinitely.

\section{Conclusion}

The project of the Ob-Yenisei Canal construction has undergone significant changes that have affected the result of the implementation. The decision to reduce the dimensions of the Ob-Yenisei waterway to a "local" canal was based on assumptions of phased construction and starting of shipping before the end of construction works. These adjustments were made by engineers and were approved by the Ministry of communication lines and the State Council. Those data became the main provisions of the draft, which was reduced to the execution of the first phase of the original project, drawn up by B. A. Aminov. That was fundamentally different from the original plan.

In approving the project and the decision to start the construction of the Ob-Yenisei Canal, the Ministry of communication lines used the data which were considered insufficient by engineers. The State Council has allocated money for the first phase of the construction, wanting to make the justification of the Ob-Yenisei Canal navigation by means of small vessels. In the conditions of the absence of process modelling techniques, it was one of the possible ways to check the viability of the projects. After the first phase of the construction, financing of the Ob-Yenisei Canal continued with the aim of expanding and modernizing, as it was planned in the Ministry of communication lines. However, it was financing by smaller quantities and even the existing allocated funds were spent ineffectively. The beginning of the Trans-Siberian railway construction made waterways modernization unnecessary, leading to fatal consequences for the $\mathrm{Ob}$ Yenisei Canal.

\section{References}

1. I.A. Ageev, V.P. Zinovyev, M.V. Netesova, V.V. Ageeva, M.S. Mironova, Modern Applied Science, 9(9), 194-204 (2015)

2. I.A. Ageev, V.V. Ageeva, Procedia - Social and Behavioral Sciences, 166, 24-29 (2015)

3. H. Priemus, Transportation Planning and Technology, 23(2), 83-103 (1999)

4. A. Hijdra, J. Woltjer, J. Arts, Transport Policy, 42, 64-74 (2015).

5. F. Southworth, B.E. Peterson, Transportation Research Part C: Emerging Technologies, 8(1-6), 147-166 (2000)

6. S.R. Stephenson, L.W. Brigham, L.C. Smith, Polar Geography, 37(2), 111-133 (2014)

7. M.V. Shilovskiy, Bulletin of Nizhnevartovsk State University, 3, 8-13 (2008)

8. P. Josephson, Journal of Transport History, 29(2), 237-239 (2008)

9. P. Josephson, Russian Review, 70(3), 419-439 (2011)

10. V.N. Bolshakov, Bulletin of the Tomsk State University, 295, 105-110 (2007)

11. A.K. Sidensner, Proceedings of the Russian Imperial Geographical Society, 14(3), 205-252 (1878)

12. The Russian State Historical Archive

13. I.I. Avgustovsky, The Ob-Yenisei Canal and the role of the waterways from the lake of Baikal to the river Ob (Saint Petersburg, 1885) 